DOI: $10.19195 / 0524-4544.326 .10$

DARIUSZ P. KAŁA

Kancelaria Prawna „LexKała”, Zielonka

\title{
Aktualne tendencje orzecznicze w sprawach finansowych ochotniczych straży pożarnych
}

\section{Wstęp}

Finansowanie ochotniczych straży pożarnych (dalej: OSP) jest jednym z najważniejszych elementów problematyki funkcjonowania OSP. Po pierwsze, z tego względu że zapewnia trwanie i rozwój OSP w systemie ochrony przeciwpożarowej, a po drugie, dlatego że system finansowania OSP jest dosyć zróżnicowany, a przez to skomplikowany. Wynika on z charakteru prawnego OSP jako osoby prawnej działającej $\mathrm{w}$ formie stowarzyszenia zaliczanego do organizacji non profit (tak zwany trzeci sektor), czyli organizacji de facto prywatnoprawnej, ale wykonującej zadania publiczne, przed wszystkim z zakresu ochrony przeciwpożarowej.

Finanse OSP to pokaźna paleta środków, która z jednej strony przeznaczana jest na finansowanie OSP jako osoby prawnej, z drugiej zaś środki te trafiają wprost do strażaków ochotników jako członków stowarzyszeń, stając się ich dochodami prywatnymi.

Finansowanie OSP $\mathrm{w}$ naszym systemie prawa jest regulowane przez kilkadziesiąt aktów prawnych, których nie sposób w tym miejscu wyliczyć ${ }^{1}$. Na gruncie tego stanu prawnego pojawia się coraz więcej orzecznictwa - zarówno sądów (powszechnych, administracyjnych), jak i organów administracji (regionalnych izb obrachunkowych, wojewodów, izb skarbowych, krajowa izb odwoławczych). Celem artykułu jest przedstawienie najnowszych orzeczeń z wybranych obszarów finansowania OSP, wskazujących nowe trendy orzecznicze.

${ }^{1}$ Szerzej zob. D.P. Kała, Ekwiwalent pieniężny dla członków ochotniczych straży pożarnych, Gdańsk 2018; D.P. Kała, Dotacje dla ochotniczych straży pożarnych, Zielonka 2015; D.P. Kała, Sto pytań do prawnika o ochotnicze straże pożarne. Poradnik praktyczny, t. 1, Gdańsk 2012. 


\section{Ekwiwalent pieniężny dla członków OSP}

Zgodnie z art. 28 ust. 1-3 ustawy z dnia 24 sierpnia 1991 roku o ochronie przeciwpożarowej ${ }^{2}$ członek OSP, który uczestniczył w działaniu ratowniczym lub szkoleniu pożarniczym organizowanym przez Państwową Straż Pożarną lub gminę, otrzymuje ekwiwalent pieniężny. Jego wysokość ustala rada gminy w drodze uchwały. Nie może ona jednak przekraczać 1/175 przeciętnego wynagrodzenia, ogłoszonego przez Prezesa Głównego Urzędu Statystycznego w Dzienniku Urzędowym Rzeczypospolitej Polskiej „Monitor Polski” na podstawie art. 20 pkt 2 ustawy z dnia 17 grudnia 1998 roku o emeryturach i rentach z Funduszu Ubezpieczeń Społecznych przed dniem ustalenia ekwiwalentu, za każdą godzinę udziału w działaniu ratowniczym lub szkoleniu pożarniczym. Ekwiwalent jest wypłacany z budżetu gminy. Nie przysługuje członkowi OSP za czas nieobecności w pracy, za który zachował wynagrodzenie. Problematyka ekwiwalentu była przedmiotem kilkunastu orzeczeń sądów administracyjnych oraz sądów powszechnych ${ }^{3}$.

Najnowszym opublikowanym orzeczeniem sądowym pozostaje postanowienie Naczelnego Sądu Administracyjnego z dnia 20 maja 2016 roku (I OSK 360/16) i poprzedzające je postanowienie Wojewódzkiego Sądu Administracyjnego w Szczecinie z dnia 24 listopada 2015 roku (II SAB/Sz 135/15) ${ }^{4}$. Oba orzeczenia

2 Ustawa z dnia 24 sierpnia 1991 roku o ochronie przeciwpożarowej (tekst jedn. Dz.U. z 2018 r. poz. 620 z późn. zm.), dalej: u.ppoż.

3 Zob. Wyrok Wojewódzkiego Sądu Administracyjnego w Lublinie z dnia 29 grudnia 2005 roku, III SA/Lu 565/05; wyrok Naczelnego Sądu Administracyjnego z dnia 13 lipca 2006 roku, I OSK 614/06; wyrok Sądu Rejonowego w Brzesku z dnia 23 stycznia 2008 roku, I C 98/07; wyrok Sądu Okręgowego w Tarnowie z dnia 5 czerwca 2008 roku, I Ca 141/08; wyrok Wojewódzkiego Sądu Administracyjnego we Wrocławiu z dnia 4 marca 2009 roku, IV SA/Wr 33/09; wyrok Wojewódzkiego Sądu Administracyjnego w Gliwicach z dnia 24 kwietnia 2009 roku, IV SA/Gl 186/09; wyrok Sądu Najwyższego z dnia 14 maja 2009 roku, I UK 351/08; wyrok Wojewódzkiego Sądu Administracyjnego w Gliwicach z dnia 10 czerwca 2009 roku, IV SA/G1 257/09; wyrok Wojewódzkiego Sądu Administracyjnego w Gliwicach z dnia 22 czerwca 2009 roku, IV SA/G1 236/09; wyrok Wojewódzkiego Sądu Administracyjnego w Gliwicach z dnia 23 lipca 2009 roku, IV SA/Gl 270/09; wyrok Wojewódzkiego Sądu Administracyjnego we Wrocławiu z dnia 16 września 2009 roku, IV SA/Wr 93/09; wyrok Wojewódzkiego Sądu Administracyjnego w Opolu z dnia 3 grudnia 2009 roku, II SA/Op 380/09; wyrok Naczelnego Sądu Administracyjnego z dnia 21 stycznia 2010 roku, I OSK 1298/09; wyrok Naczelnego Sądu Administracyjnego z dnia 21 stycznia 2010 roku, I OSK 1115/09; postanowienie Naczelnego Sądu Administracyjnego z dnia 27 stycznia 2010 roku, I OSK 1389/09; wyrok Wojewódzkiego Sądu Administracyjnego w Szczecinie z dnia 4 listopada 2011 roku, II SA/Sz 848/11; wyrok Wojewódzkiego Sądu Administracyjnego w Gliwicach z dnia 5 marca 2013 roku, IV SA/Gl 568/12; wyrok Wojewódzkiego Sądu Administracyjnego we Wrocławiu z dnia 1 lipca 2014 roku, IV SA/Wr 100/14; postanowienie Wojewódzkiego Sądu Administracyjnego w Szczecinie z dnia 24 listopada 2015 roku, II SAB/Sz 135/15; postanowienie Naczelnego Sądu Administracyjnego z dnia 20 maja 2016 roku, I OSK 360/16.

4 Orzeczenia te zostały po raz pierwszy omówione i skomentowane w pracach: D.P. Kała, K. Sowa, Glosa do postanowienia Wojewódzkiego Sadu Administracyjnego w Szczecinie z dnia 
dotyczyły kwestii zarządzenia wydawanego w procedurze wypłaty ekwiwalentu. Naczelny Sąd Administracyjny uznał, że dopuszczalne jest wydanie przez wójta zarządzenia w sprawie wykonania uchwały dotyczącej wysokości ekwiwalentu, ale nie ma on takiego prawnego obowiązku, oraz że uchwała w sprawie wysokości ekwiwalentu może być przez wójta wykonana także w inny sposób niż przez wydanie zarządzenia 5 .

Problematyka ekwiwalentu znacznie częściej jest przedmiotem rozstrzygnięć nadzorczych wojewodów ${ }^{6}$.

Jednym z najnowszych orzeczeń jest rozstrzygnięcie nadzorcze Wojewody Kujawsko-Pomorskiego z dnia 2 maja 2018 roku $(49 / 2018)^{7}$. Wojewoda orzekł o nieważności uchwały nr XXIX/285/2018 Rady Miejskiej w Lubieniu Kujawskim z dnia 28 marca 2018 roku w sprawie ustalenia wysokości ekwiwalentu pieniężnego dla członków OSP z terenu gminy Lubień Kujawski w części określonej w $§ 1$ pkt 2 w zakresie słów ,i ćwiczeniach”.

W dniu 28 marca 2018 roku Rada Miejska w Lubieniu Kujawskim podjęła uchwałę nr XXIX/285/2018 w sprawie ustalenia wysokości ekwiwalentu pieniężnego dla członków OSP z terenu gminy Lubień Kujawski. Przedmiotowa uchwała wpłynęła do organu nadzoru w dniu 3 kwietnia 2018 roku Zawiadomieniem z dnia 16 kwietnia 2018 roku (znak: WNK.DW.IV.4131.15.2018) organ nadzoru wszczął postępowanie nadzorcze w sprawie stwierdzenia nieważności uchwały. Przewodniczący Rady Miejskiej w Lubieniu Kujawskim w wyznaczonym terminie nie ustosunkował się do stwierdzeń zawartych w zawiadomieniu o wszczęciu postępowania nadzorczego.

Rada Miejska w Lubieniu Kujawskim w $§ 1$ pkt 2 uchwały postanowiła:

24 listopada 2015 r., II SAB/Sz 135/15, „Orzecznictwo Sądów Polskich” 2016, z. 10; idem, Ekwiwalent pieniężny dla członków..., s. 45-49.

5 Szerzej na ten temat zob. D.P. Kała, Ekwiwalent pieniężny dla czlonków..., s. 45-49 wraz $z$ oceną tego orzeczenia.

6 Przykładowo zob. rozstrzygnięcie nadzorcze Wojewody Dolnośląskiego z dnia 9 maja 2011 roku, NK N.4131.339.2011.JK8, Lex nr 962966; rozstrzygnięcie nadzorcze Wojewody Dolnośląskiego z dnia 13 lutego 2012 roku, NK-N11.4131.134.2012.AS2, Lex nr 1126761; rozstrzygnięcie nadzorcze Wojewody Kujawsko-Pomorskiego z dnia 28 stycznia 2009 roku, WNK/DW.IV.GS.0911-2/09, Lex $\mathrm{nr}$ 488145; rozstrzygnięcie nadzorcze Wojewody Małopolskiego z dnia 1 czerwca 2009 roku, PN.V.0911-24-09, Lex nr 514084; rozstrzygnięcie nadzorcze Wojewody Małopolskiego z dnia 31 marca 2009 roku, PN.II.0911-76-09, Lex nr 523740; rozstrzygnięcie nadzorcze Wojewody Dolnośląskiego z dnia 4 maja 2009 r., NK.II.0911-16/303/09, Lex nr 508117; rozstrzygnięcie nadzorcze Wojewody Lubuskiego z dnia 26 lipca 2011 roku, NK.I.4131.294.2011.AZIE, Lex nr 964000; rozstrzygnięcie nadzorcze Wojewody Zachodniopomorskiego z dnia 20 grudnia 2011 roku, NK.4.4131.292.2011.SA, Lex nr 1109148; rozstrzygnięcie nadzorcze Wojewody Dolnośląskiego z dnia 13 lutego 2012 roku, NK-N11.4131.134.2012.AS2, Lex nr 1126761; rozstrzygnięcie nadzorcze Wojewody Lubuskiego z dnia 23 lipca 2012 roku, NK-I.4131.241.2012.IWit, Lex nr 1187506.

7 Dziennik Urzędowy Województwa Kujawsko-Pomorskiego, www.edzienniki.bydgoszcz. uw.gov.pl (dostęp: 4.07.2018). 
Ustala się wysokość ekwiwalentu pieniężnego dla członków ochotniczych straży pożarnych z terenu Gminy Lubień Kujawski za udział szkoleniach i ćwiczeniach pożarniczych organizowanym przez Państwową Straż Pożarną lub Gminę Lubień Kujawski w wysokości 10 zł (dziesięć złotych) za każdą godzinę.

W przepisie uchwały organ stanowiący gminy Lubień Kujawski oprócz ekwiwalentu pieniężnego za udział w szkoleniach pożarniczych przewidział także ekwiwalent pieniężny za udział w ćwiczeniach pożarniczych.

Organ nadzoru, odwołując się do częściowo nietrafnej tezy orzeczenia Wojewódzkiego Sądu Administracyjny we Wrocławiu z dnia 1 lipca 2014 roku (sygn. akt IV SA/Wr 100/14) ${ }^{8}$, uznał:

Mając zatem na względzie powyższe, w ocenie organu nadzoru Rada Miejska w Lubieniu Kujawskim na podstawie art. 28 ust. 1 ustawy o ochronie przeciwpożarowej upoważniona była wyłącznie do ustalenia wysokości ekwiwalentu pieniężnego za udział członków ochotniczych straży pożarnych w działaniu ratowniczym lub szkoleniu pożarniczym organizowanym przez Państwową Straż Pożarną lub gminę.

Z twierdzeniem wojewody należy się zgodzić, ponieważ delegacja ustawowa zawarta $\mathrm{w}$ art. 28 upoważnia jedynie do ustalenia stawki ekwiwalentu za udział w działaniu ratowniczym lub szkoleniu pożarniczym. Nie można natomiast zgodzić się z ,lansowaną" pośrednio przez wojewodę tezą WSA we Wrocławiu, że:

można zatem przyjąć, że pojęcie „szkolenia” obejmuje zarówno nabywanie przez kogoś wiedzy teoretycznej (np. na wykładach, kursach, itp.), jak i praktycznej, np. poprzez udział w zawodach pożarniczych, manewrach i ćwiczeniach, podczas których trenowane są różne warianty działan pożarniczych.

Ogólnie należy uznać, że za udział w ćwiczeniach ratowniczych i zawodach ratowniczych nie należy płacić ekwiwalentu pieniężnego członkom OSP, dopóki jednoznacznie nie postanowi tak ustawodawca ${ }^{9}$.

\section{Dotacje}

Zgodnie z art. 32 ust. $3 b$ u.ppoż. jednostki samorządu terytorialnego mogą przekazywać OSP środki pieniężne w formie dotacji. Zgodnie z art. 221 ust. 1 ustawy z dnia 27 sierpnia 2009 roku o finansach publicznych ${ }^{10}$ podmioty nie-

8 Zob. D.P. Kała, Ekwiwalent pieniężny za ćwiczenia i zawody dla członka ochotniczej straży pożarnej. Glosa do wyroku Wojewódzkiego Sadu Administracyjnego we Wroctawiu z 1.07.2014 r., IV SA/Wr 100/14, „Finanse Komunalne” 2015, nr 12.

9 Szerzej na ten temat zob. D.P. Kała, Ekwiwalent pieniężny dla członków..., s. 63-64; idem, Ekwiwalent za udział w ćwiczeniach ratowniczych, „Strażak” 2014, nr 12, s. 56-57; idem, Ekwiwalent pieniężny za ćwiczenia..., s. $71 \mathrm{n}$.

10 Ustawa z dnia 27 sierpnia 2009 roku o finansach publicznych (tekst jedn. Dz.U. z 2017 r. poz. 2077 z późn. zm). 
zaliczane do sektora finansów publicznych i niedziałające w celu osiągnięcia zysku mogą otrzymywać z budżetu jednostki samorządu terytorialnego dotacje celowe na cele publiczne, związane $\mathrm{z}$ realizacją zadań tej jednostki, a także na dofinansowanie inwestycji związanych z realizacją tych zadań. Zgodnie z art. 5 ust. 1 ustawy z dnia 24 kwietnia 2003 roku o działalności pożytku publicznego i o wolontariacie ${ }^{11}$ organy administracji publicznej prowadzą działalność w sferze zadań publicznych, o której mowa w art. 4, we współpracy z organizacjami pozarządowymi oraz podmiotami wymienionymi w art. 3 ust. 3 , prowadzącymi, odpowiednio do terytorialnego zakresu działania organów administracji publicznej, działalność pożytku publicznego w zakresie odpowiadającym zadaniom tych organów. Organizacjami pozarządowymi są: 1. niebędące jednostkami sektora finansów publicznych w rozumieniu ustawy z dnia 27 sierpnia 2009 roku o finansach publicznych lub przedsiębiorstwami, instytutami badawczymi, bankami i spółkami prawa handlowego będącymi państwowymi lub samorządowymi osobami prawnymi, 2. niedziałające $\mathrm{w}$ celu osiągnięcia zysku — osoby prawne lub jednostki organizacyjne nieposiadające osobowości prawnej, którym odrębna ustawa przyznaje zdolność prawną, w tym fundacje i stowarzyszenia, z zastrzeżeniem ust. 4 (art. 3 ust. 2 o działalności pożytku publicznego i o wolontariacie).

Na podstawie przywołanych przepisów OSP mogą otrzymywać dotacje z jednostek samorządu terytorialnego ${ }^{12}$.

Na bazie przepisów dotyczących udzielania dotacji dla OSP wyrasta przede wszystkim orzecznictwo regionalnych izb obrachunkowych (dalej: RIO) ${ }^{13}$.

Jednym z najnowszych orzeczeń RIO jest uchwała $\mathrm{nr}$ 51/2018 Kolegium Regionalnej Izby Obrachunkowej we Wrocławiu z dnia 28 marca 2018 roku $^{14}$. Kolegium Regionalnej Izby Obrachunkowej we Wrocławiu stwierdziło nieważność uchwały Rady Miasta Piechowice nr 295/XLVIII/2018 z dnia 27 lutego 2018 roku

11 Ustawa z dnia 24 kwietnia 2003 roku o działalności pożytku publicznego i o wolontariacie (tekst jedn. Dz.U. z 2018 r. poz. 450 z późn. zm).

12 Szerzej na ten temat zob. D.P. Kała, Dotacje...

13 Zob. np. uchwała Regionalnej Izby Obrachunkowej w Krakowie z dnia 4 sierpnia 2010 roku, KI-411/202/10, Lex nr 726590; uchwała Regionalnej Izby Obrachunkowej w Warszawie z dnia 14 sierpnia 2007 roku, 121/K/2007, Legalis nr 186644; uchwała Regionalnej Izby Obrachunkowej w Opolu z dnia 6 sierpnia 2008 roku, 17/86/2008, Legalis nr 294375; uchwała Regionalnej Izby Obrachunkowej w Warszawie z dnia 18 marca 2009 roku, 70/K/09, Legalis nr 221411; uchwała Regionalnej Izby Obrachunkowej w Warszawie z dnia 29 kwietnia 2009 roku, 88/K/09, Legalis 284950; uchwała Regionalnej Izby Obrachunkowej w Warszawie z dnia 29 kwietnia 2009 roku, 98/K/09, Legalis nr 284956; uchwała Regionalnej Izby Obrachunkowej w Lublinie z dnia 28 czerwca 2010 roku, 100/10, Lex nr 652786; uchwała Regionalnej Izby Obrachunkowej w Opolu z dnia 30 czerwca 2010 roku, 14/29/2010, Legalis nr 291478; uchwała Regionalnej Izby Obrachunkowej w Olsztynie z dnia 21 października 2010 roku, 0102-206/10, Legalis nr 299127; uchwała Regionalnej Izby Obrachunkowej w Rzeszowie z dnia 3 kwietnia 2012 roku, VII/1472/12, Lex nr 1163920; uchwała Regionalnej Izby Obrachunkowej w Poznaniu z dnia 28 listopada 2012 roku, 21/1482/2012, Legalis nr 569570.

14 https://bip.wroclaw.rio.gov.pl/dokumenty/uchwaly/2018/0511806031.pdf (dostęp: 5.07.2018). 
w sprawie udzielenia dotacji celowej OSP Piechowice - wobec podjęcia jej bez podstawy prawnej. Uchwała Rady Miasta Piechowice wpłynęła do Regionalnej Izby Obrachunkowej we Wrocławiu w dniu 8 marca 2018 roku. Przedmiotową uchwałą Rada Miasta Piechowice postanowiła o udzieleniu OSP Piechowice dotacji celowej z przeznaczeniem na zakup wyposażenia osobistego i ochronnego dla członków Jednostki Operacyjno-Technicznej OSP Piechowice. W § 3 badanej uchwały zapisano, że szczegółowe warunki udzielenia i rozliczenia dotacji zostaną określone w stosownym porozumieniu. Kolegium Izby stwierdziło, że została ona podjęta bez podstawy prawnej. Kolegium uznało, że: ,żaden z obowiązujących przepisów, w tym żaden z przepisów powołanych $\mathrm{w}$ podstawie prawnej uchwały ${ }^{15}$, nie stanowi delegacji dla organu stanowiącego gminy do podjęcia odrębnej uchwały w sprawie udzielenia dotacji dla ochotniczej straży pożarnej. Na podstawie art. 32 ust. 3b ustawy o ochronie przeciwpożarowej w budżecie gminy mogą być planowane dotacje dla OSP, których udziela burmistrz w toku wykonywania budżetu. Upoważnienie dla burmistrza do zawarcia umowy dotyczącej udzielenia dotacji celowej wynika wprost z art. 250 ust. 1 ustawy o finansach publicznych".

Orzeczenie to należy uznać za trafne. Wpisuje się ono w linię orzeczniczą RIO we Wrocławiu ${ }^{16}$. Jest ono zgodne z poglądami wyrażanymi przez RIO w Lublinie, w Poznaniu, Rzeszowie i Warszawie ${ }^{17}$. W tym wypadku należy opowiedzieć się przeciwko orzecznictwu RIO w Krakowie, które zajmuje odmienne stanowisko.

\section{Rekompensata pieniężna za utratę zdrowia}

Zgodnie z 26 ust. 1-4 u.ppoż. członkowi OSP, który w związku z udziałem w działaniach ratowniczych lub ćwiczeniach doznał uszczerbku na zdrowiu wskutek wypadku, za czas niezdolności do pracy, za który nie zachował prawa do wynagrodzenia albo nie otrzymał zasiłku chorobowego lub świadczenia rehabilitacyjnego na podstawie odrębnych przepisów, przysługuje, na jego wniosek, re-

15 Art. 18 ust. 2 pkt 15 ustawy z dnia 8 marca 1990 roku o samorządzie gminnym (Dz.U. z 2017 r. poz. 1875 i 2232 oraz z 2018 r. poz. 130); art. 216 ust. 2 pkt 5 i art. 220 ust. 1 ustawy z dnia 27 sierpnia 2009 roku o finansach publicznych (Dz.U. z 2017 r. poz. 2077) oraz art. 29 pkt 2 ustawy z dnia 24 sierpnia 1991 r. o ochronie przeciwpożarowej (Dz.U. z 2017 r. poz. 736 z późn. zm.).

16 Zob. uchwała nr 28/2015 Kolegium Regionalnej Izby Obrachunkowej we Wrocławiu z dnia 23 marca 2015 roku; uchwała nr 85/2017 Kolegium Regionalnej Izby Obrachunkowej we Wrocławiu z dnia 27 września 2017 roku; uchwała nr 93/2017 Kolegium Regionalnej Izby Obrachunkowej we Wrocławiu z dnia 8 listopada 2017 roku; uchwała nr 92/2017 Kolegium Regionalnej Izby Obrachunkowej we Wrocławiu z dnia 25 października 2017 roku; uchwała nr 103/2017 Kolegium Regionalnej Izby Obrachunkowej we Wrocławiu z dnia 29 listopada 2017 roku. Dostęp do uchwał: https://bip.wroclaw.rio.gov.pl.

17 Por. D.P. Kała, Dotacje..., s. 107-109. 
kompensata pieniężna, zwana dalej „rekompensatą”. Rekompensata przysługuje za każdy dzień niezdolności do pracy w wysokości 1/30 minimalnego wynagrodzenia za pracę ustalanego na podstawie ustawy z dnia 10 października 2002 roku o minimalnym wynagrodzeniu za pracę. Rekompensatę przysługującą członkowi OSP niewłączonej do krajowego systemu ratowniczo-gaśniczego ustala i wypłaca podmiot ponoszący koszty funkcjonowania jednostki ochrony przeciwpożarowej jako zadanie zlecone z zakresu administracji rządowej. Rekompensatę przysługującą członkowi OSP włączonej do krajowego systemu ratowniczo-gaśniczego ustala i wypłaca właściwy komendant wojewódzki Państwowej Straży Pożarnej ${ }^{18}$.

Regulacja prawna dotycząca rekompensaty jest stosunkowo „młoda”, ponieważ została dodana do ustawy o ochronie przeciwpożarowej ustawą z dnia 15 maja 2015 roku o zmianie ustawy o ochronie przeciwpożarowej ${ }^{19}$, z mocą obowiązywania od 1 stycznia 2016 roku. W związku z tym przepisy te ucierają się dopiero w praktyce i nie mają jeszcze rozbudowanego orzecznictwa. Jak dotychczas jedynym precedensowym i jednocześnie korzystnym dla OSP orzeczeniem jest interpretacja Dyrektora Izby Skarbowej z dnia 18 października 2017 roku $^{20}$. W orzeczeniu stwierdzono, że:

W przypadku przychodów członków Ochotniczych Straży Pożarnych z tytułu uczestnictwa w szkoleniach lub akcjach ustawa o podatku dochodowym od osób fizycznych przewiduje zwolnienie przedmiotowe. Należy zatem uznać, że obejmuje ono swoim zakresem również rekompensaty pieniężne i wyrównania, o których mowa w art. 26a ustawy o ochronie przeciwpożarowej. Wartość rekompensaty pieniężnej i wyrównania dla członka OSP na podstawie art. 21 ust. 1 pkt 44 ustawy o podatku dochodowym od osób fizycznych jest zwolniona z opodatkowania, zatem na Komendzie nie ciąży obowiązek wystawienia informacji PIT-8C.

Orzeczenie to wpisuje się $\mathrm{w}$ trend orzeczniczy dotyczący świadczeń majątkowych dla członków OSP. Pamiętać bowiem należy, że izby skarbowe stoją na jednoznacznym stanowisku, że ekwiwalent dla członka OSP z tytułu udziału w działaniach ratowniczych i szkoleniach pożarniczych także jest wolny od podatku ${ }^{21}$. Podobnie zwolnione jest $\mathrm{z}$ podatku odszkodowanie wypłacane przez gminę strażakowi OSP z tytułu wypadku w związku z udziałem w działaniach ratowniczych ${ }^{22}$.

18 Szerzej na ten temat zob. D.P. Kała, Rekompensata za uszczerbek na zdrowiu, „Strażak” 2016, nr 1; idem, Procedura wyptaty rekompensaty za uszczerbek na zdrowiu, „Strażak” 2016, nr 2.

19 Ustawa z dnia 15 maja 2015 roku o zmianie ustawy o ochronie przeciwpożarowej (Dz.U. z 2015 r. poz. 867).

${ }^{20}$ Interpretacja indywidualnaz dnia 18 października 2017 r., 0112-KDIL3-1.4011.261.2017.1.IM, https://interpretacje-podatkowe.org (dostęp: 5.07.2018). Interpretacja ta po raz pierwszy została omówiona w publikacji D.P. Kała, Rekompensata dla członka OSP a podatek dochodowy, www.lexfire.pl (dostęp: 7.09.2018).

21 Por. D.P. Kała, Ekwiwalent pieniężny dla członków..., s. 112-114.

22 Por. D.P. Kała, Opodatkowanie odszkodowania wypłaconego strażakowi OSP, „Strażak” 2017, nr 5, gdzie omówiono interpretację podatkową Dyrektora Izby Skarbowej w Bydgoszczy z dnia 8 lipca 2016 roku, ITPB2/4511-374/16/TJ. 


\section{Bibliografia}

Kała D.P., Dotacje dla Ochotniczych Straży Pożarnych, Zielonka 2015.

Kała D.P., Ekwiwalent pieniężny dla członków Ochotniczych Straży Pożarnych, Gdańsk 2018.

Kała D.P., Ekwiwalent pieniężny za ćwiczenia i zawody dla członka ochotniczej straży pożarnej. Glosa do wyroku Wojewódzkiego Sądu Administracyjnego we Wrocławiu z 1.07.2014 r., IV SA/ Wr 100/14, „Finanse Komunalne” 2015, nr 12.

Kała D.P., Ekwiwalent za udziat w ćwiczeniach ratowniczych, „Strażak” 2014, nr 12.

Kała D.P., Opodatkowanie odszkodowania wyptaconego strażakowi OSP, „Strażak” 2017, nr 5.

Kała D.P., Procedura wypłaty rekompensaty za uszczerbek na zdrowiu, „Strażak” 2016, nr 2.

Kała D.P., Rekompensata dla członka OSP a podatek dochodowy, www.lexfire.pl.

Kała D.P., Rekompensata za uszczerbek na zdrowiu, „Strażak” 2016, nr 1.

Kała D.P., Sto pytań do prawnika o Ochotnicze Straże Pożarne. Poradnik praktyczny, t. 1, Gdańsk 2012.

Kała D.P., Sowa K., Glosa do postanowienia Wojewódzkiego Sądu Administracyjnego w Szczecinie z dnia 24 listopada 2015 r., II SAB/Sz 135/15, „Orzecznictwo Sądów Polskich” 2016, z. 10.

\section{Wykaz aktów prawnych}

Ustawa z dnia 24 sierpnia 1991 roku o ochronie przeciwpożarowej (tekst jedn. Dz.U. z 2018 r. poz. 620 z późn. zm.).

Ustawa z dnia 24 kwietnia 2003 roku o działalności pożytku publicznego i o wolontariacie (tekst jedn. Dz.U. z 2018 r. poz. 450 z późn. zm.).

Ustawa z dnia 27 sierpnia 2009 roku o finansach publicznych (tekst jedn. Dz.U. z 2017 r. poz. 2077 z późn. $z m$.).

Ustawa z dnia 15 maja 2015 roku o zmianie ustawy o ochronie przeciwpożarowej (Dz.U. z 2015 r. poz. 867).

\section{Wykaz orzecznictwa}

Interpretacja indywidualna z dnia 18 października 2017 roku, 0112-KDIL3-1.4011.261.2017.1.IM, https://interpretacje-podatkowe.org.

Postanowienie Naczelnego Sądu Administracyjnego z dnia 27 stycznia 2010 roku, I OSK 1389/09.

Postanowienie Wojewódzkiego Sądu Administracyjnego w Szczecinie z dnia 24 listopada 2015 roku, II SAB/Sz 135/15.

Postanowienie Naczelnego Sądu Administracyjnego z dnia 20 maja 2016 roku, I OSK 360/16.

Rozstrzygnięcie nadzorcze Wojewody Kujawsko-Pomorskiego z dnia 28 stycznia 2009 roku, WNK/DW.IV.GS.0911-2/09, Lex nr 488145.

Rozstrzygnięcie nadzorcze Wojewody Małopolskiego z dnia 31 marca 2009 roku, PN.II.0911-76-09, Lex nr 523740.

Rozstrzygnięcienadzorcze Wojewody Dolnośląskiegozdnia4maja2009 roku, NK.II.0911-16/303/09, Lex nr 508117,

Rozstrzygnięcie nadzorcze Wojewody Małopolskiego z dnia 1 czerwca 2009 roku, PN.V.0911-2409, Lex nr 514084.

Rozstrzygnięcie nadzorcze Wojewody Dolnośląskiego z dnia 9 maja 2011 roku, NK N.4131.339.2011. JK8, Lex nr 962966. 
Rozstrzygnięcie nadzorcze Wojewody Lubuskiego z dnia 26 lipca 2011 roku, NK.I.4131.294.2011. AZIE, Lex nr 964000.

Rozstrzygnięcie nadzorcze Wojewody Zachodniopomorskiego z dnia 20 grudnia 2011 roku, NK.4.4131.292.2011.SA, Lex nr 1109148.

Rozstrzygnięcie nadzorcze Wojewody Dolnośląskiego z dnia 13 lutego 2012 roku, NK-N11.4131.134.2012. AS2, Lex nr 1126761.

Rozstrzygnięcie nadzorcze Wojewody Lubuskiego z dnia 23 lipca 2012 roku, NK-I.4131.241.2012. IWit, Lex nr 1187506.

Uchwała Regionalnej Izby Obrachunkowej w Warszawie z dnia 14 sierpnia 2007 roku, 121/K/2007, Legalis nr 186644.

Uchwała Regionalnej Izby Obrachunkowej w Opolu z dnia 6 sierpnia 2008 roku, 17/86/2008, Legalis $\mathrm{nr} 294375$.

Uchwała Regionalnej Izby Obrachunkowej w Warszawie z dnia 18 marca 2009 roku, 70/K/09, Legalis $\mathrm{nr} 221411$.

Uchwała Regionalnej Izby Obrachunkowej w Warszawie z dnia 29 kwietnia 2009 roku, 88/K/09, Legalis 284950.

Uchwała Regionalnej Izby Obrachunkowej w Lublinie z dnia 28 czerwca 2010 roku, 100/10, Lex nr 652786.

Uchwała Regionalnej Izby Obrachunkowej w Opolu z dnia 30 czerwca 2010 roku, 14/29/2010, Legalis nr 291478.

Uchwała Regionalnej Izby Obrachunkowej w Krakowie z dnia 4 sierpnia 2010 roku, KI-411/202/10, Lex nr 726590.

Uchwała Regionalnej Izby Obrachunkowej w Olsztynie z dnia 21 października 2010 roku, 0102-206/10, Legalis nr 299127.

Uchwała Regionalnej Izby Obrachunkowej w Rzeszowie z dnia 3 kwietnia 2012 roku, VII/1472/12, Lex nr 1163920.

Uchwała Regionalnej Izby Obrachunkowej w Poznaniu z dnia 28 listopada 2012 roku, 21/1482/2012, Legalis nr 569570.

Uchwała nr 28/2015 Kolegium Regionalnej Izby Obrachunkowej we Wrocławiu z dnia 23 marca 2015 roku.

Uchwała nr 85/2017 Kolegium Regionalnej Izby Obrachunkowej we Wrocławiu z dnia 27 września 2017 roku.

Uchwała nr 93/2017 Kolegium Regionalnej Izby Obrachunkowej we Wrocławiu z dnia 8 listopada 2017 roku.

Uchwała nr 92/2017 Kolegium Regionalnej Izby Obrachunkowej we Wrocławiu z dnia 25 października 2017 roku.

Uchwała nr 103/2017 Kolegium Regionalnej Izby Obrachunkowej we Wrocławiu z dnia 29 listopada 2017 roku.

Wyrok Wojewódzkiego Sądu Administracyjnego w Lublinie z dnia 29 grudnia 2005 roku, III SA/Lu 565/05.

Wyrok Naczelnego Sądu Administracyjnego z dnia 13 lipca 2006 roku, I OSK 614/06.

Wyrok Sądu Rejonowego w Brzesku z dnia 23 stycznia 2008 roku, I C 98/07.

Wyrok Sądu Okręgowego w Tarnowie z dnia 5 czerwca 2008 roku, I Ca 141/08.

Wyrok Wojewódzkiego Sądu Administracyjnego we Wrocławiu z dnia 4 marca 2009 roku, IV SA/Wr 33/09.

Wyrok Wojewódzkiego Sądu Administracyjnego w Gliwicach z dnia 24 kwietnia 2009 roku, IV SA/G1 186/09.

Wyrok Sądu Najwyższego z dnia 14 maja 2009 roku, I UK 351/08.

Wyrok Wojewódzkiego Sądu Administracyjny w Gliwicach z dnia 10 czerwca 2009 roku, IV SA/G1 257/09. 
Wyrok Wojewódzkiego Sądu Administracyjnego w Gliwicach z dnia 22 czerwca 2009 roku, IV SA/G1 236/09.

Wyrok Wojewódzkiego Sądu Administracyjnego w Gliwicach z dnia 23 lipca 2009 roku, IV SA/G1 270/09.

Wyrok Wojewódzkiego Sądu Administracyjnego we Wrocławiu z dnia 16 września 2009 roku, IV SA/Wr 93/09.

Wyrok Wojewódzkiego Sądu Administracyjnego w Opolu z dnia 3 grudnia 2009 roku, II SA/Op $380 / 09$.

Wyrok Naczelnego Sądu Administracyjnego z dnia 21 stycznia 2010 roku, I OSK 1298/09.

Wyrok Naczelnego Sądu Administracyjnego z dnia 21 stycznia 2010 roku, I OSK 1115/09.

Wyrok Wojewódzkiego Sądu Administracyjnego w Szczecinie z dnia 4 listopada 2011 roku, II SA/Sz 848/11.

Wyrok Wojewódzkiego Sądu Administracyjnego w Gliwicach z dnia 5 marca 2013 roku, IV SA/G1 568/12.

Wyrok Wojewódzkiego Sądu Administracyjnego we Wrocławiu z dnia 1 lipca 2014 roku, IV SA/Wr 100/14.

\title{
Current judicial trends in financial matters voluntary fire brigades
}

\author{
Summary
}

The aim of the study is to present the latest and current judicial trends in financial issues regarding volunteer fire. You should not pay a cash equivalent for participating in emergency and rescue exercises. Based on Article. 32 para. $3 b$ of the Fire Protection Act, subsidies for volunteer fire brigades may be planned in the commune budget. Compensation and compensation for members of volunteer fire brigades is exempt from tax.

Keywords: volunteer fire brigade, equivalent, compensation, subsidies, financing of voluntary fire brigades. 